DOI: https://doi.org/10.24127/ajpm.v8i3.2265

\title{
ANALISIS KESALAHAN REPRESENTASI SIMBOLIK MAHASISWA DALAM MENYELESAIKAN SOAL HIGH ORDER THINKING SKILL
}

\author{
Anggiana Putri Aliyanti ${ }^{1}$, Octavina Rizky Utami Putri ${ }^{2}$, Zukhrufurrohmah ${ }^{3}$ \\ 1,2,3 Universitas Muhammadiyah Malang \\ E-mail: $\quad$ anggianapa@gmail.com ${ }^{1)}$ \\ oruputri@yahoo.com ${ }^{2)}$ \\ zukhurrohmah@umm.ac.id ${ }^{3)}$
}

Received 05 September 2019; Received in revised form 4 December 2019; Accepted 24 December 2019

\begin{abstract}
Abstrak
Tujuan penelitian ini untuk mendeskripsikan kesalahan representasi simbolik mahasiswa dalam menyelesaikan permasalahan HOTS. Penelitian merupaka kualitatif deskriptif. Pengumpulan data dilakukan dengan dokumentasi dan tes. Subjek penelitian terdiri dari 9 mahasiswa yang dipilih berdasarkan hasil pengerjaan Lembar Kegiatan Mahasiswa (LKM). Hasil penelitian menunjukkan bahwa kesalahan representasi simbolik yang dilakukan oleh mahasiswa terdiri dari (1) kesalahan penulisan simbol turunan parsial, (2) kesalahan dalam menentukan hasil turunan parsial, (3) kesalahan dalam menentukan nilai fungsi turunan parsial, dan (4) kesalahan dalam memahami perintah soal. Kesalahankesalahan representasi simbolik tersebut terjadi karena beberapa faktor yaitu kurangnya pemahaman terhadap simbol - simbol turunan parsial, ketidaktelitian dalam menyelesaikan soal, tidak memperhatikan dan memahami perintah soal dengan baik, tidak teliti dalam menuliskan jawaban akhir, tidak memahami konsep turunan parsial dengan baik, dan tidak memahami konsep dalam menentukan nilai fungsi dengan baik.
\end{abstract}

Kata Kunci: HOTS; kesalahan; representasi simbolik.

\begin{abstract}
The purpose of this study is to describe the symbolic misrepresentation of students in solving HOTS problems. Research is a qualitative descriptive. Data collection is done by documentation and tests. The research subjects consisted of 9 students selected based on the results of the Student Activity Sheet (LKM). The results showed that the symbolic error made by students consisted of (1) writing errors of partial derivative symbols, (2) errors in determining the results of partial derivatives, (3) errors in determining the value of partial derivative functions, and (4) errors in understanding command matter. The errors of symbolic representation occur due to several factors, namely the lack of understanding of partial derivative symbols, inaccuracy in solving problems, not paying attention and understanding the order of questions properly, not careful in writing the final answer, not understanding the concept of partial derivatives well, and do not understand the concept of determining the value of a function properly.
\end{abstract}

Keywords: Mistake; HOTS; symbolic representation.

\section{PENDAHULUAN}

Kemampuan

representasi

memiliki hubungan yang kuat dengan kemampuan dalam memecahkan masalah dan kemampuan dalam berkomunikasi. Kemampuan representasi yang baik sangat diperlukan untuk dapat mengkomunikasikan suatu ide baik melalui diagram, gambar, grafik, maupun bentuk representasi lainnya. Masalah yang terlihat rumit akan lebih mudah diselesaikan jika memiliki kemampuan representasi yang baik (Sabirin, 2014).

Representasi merupakan struktur pola pikir dalam menghadapi masalah yang fungsinya sebagai media dalam menemukan jalan keluar dari masalah tersebut. Representasi juga dapat 
DOI: https://doi.org/10.24127/ajpm.v8i3.2265

diartikan sebagai pengutaraan pemikiran-pemikiran matematika dengan menggunakan berbagai cara seperti bahasa tulis, bahasa lisan, diagram grafik, model, dan simbol atau dengan menggunakan anggota fisik. Para pakar mengungkapkan bahwa berbagai bentuk representasi seperti diagram, ekspresi bilangan basis 10 atau biner, pecahan, grafik, dan ekspresi simbolik menjadi komponen utama dalam kurikulum matematika (Hartoyo, 2010). Representasi ini sangat diperlukan dalam pembelajaran matematika, sehingga hal ini menjadi salah satu target pencapaian dalam proses pembelajaran matematika (Sabirin, 2014). Kemampuan representasi merupakan suatu kemampuan yang berhubungan dengan pemahaman matematis. Kemampuan representasi ini digunakan dalam mengomunikasikan ide-ide matematika dengan beraneka ragam cara seperti simbol, gambar, objek nyata, ataupun tulisan. Kemampuan representasi dapat memberikan kemudahan untuk memahami konsep serta menyelesaikan permasalahan matematika yang awalnya sulit menjadi lebih mudah (Handayani, 2015). Kemampuan representasi merupakan hal yang sangat penting dalam pembelajaran matematika di samping kemampuan penalaran, kemampuan memahami konsep, komunikasi, dan pemecahan masalah. Standar proses kemampuan dalam representasi yaitu mampu membuat dan menggunakan representasi untuk mengungkapkan ide-ide matematika, mampu menggunakan representasi untuk menyelesaikan permasalahan, dan mampu menggunakan representasi dalam membuat model matematika (Maoto, Masha, \& Mokwana, 2018).

Representasi dapat digolongkan secara umum menjadi representasi visual (tabel, gambar, atau diagram grafik), representasi simbolik (numerik/ simbol aljabar, pernyataan matematika/ notasi matematik), dan representasi verbal (Khairunnisa, Rahman, \& Susanto, 2018). Salah satu jenis representasi yang digunakan dalam matematika yaitu representasi simbolik. Representasi simbolik biasanya hanya dianggap sebagai tujuan kecil yang akan dicapai dari materi matematika, namun ternyata hal ini menjadi suatu landasan penting dalam mengembangkan kemampuan berpikir kritis pada matematika yang sejalan dengan langkah-langkah pembelajaran matematika lainnya (Hartoyo, 2010). Representasi simbolik berfokus pada penggunaan simbol, variabel, dan formula dalam matematika. Representasi simbolik umumnya berupa persamaan, ekspresi, persamaan aljabar, ekspresi aljabar, dan rumus. Representasi simbolik juga dikenal dengan representasi aljabar (Hapizah, 2019). Indikator dalam representasi ekspresi matematis yaitu membuat model matematika dari representasi lain yang diberikan, membuat konjektur dari suatu pola bilangan, dan menyelesaikan masalah yang berkaitan dengan melibatkan ekspresi matematis (Suryana, 2012).

Representasi matematis dapat digunakan untuk menyelesaikan soal High Order Thinking Skill (HOTS). HOTS merupakan salah satu kemampuan dalam mengaitkan, mengubah, dan memanipulasi pengalaman dan ilmu pengetahuan yang sudah pernah diperoleh sebelumnya secara kritis, serta kreatif dalam mengambil keputusan terhadap suatu masalah (Dinni, 2018). Kemampuan menyelesaikan masalah berbasis HOTS menjadi salah satu tuntutan mahasiswa saat ini. Hal ini terjadi karena 
perkembangan zaman yang semakin pesat sehingga menuntut mahasiswa untuk kreatif, mampu berinovasi, dan produktif dalam menganalisis kebutuhan (Rodiawati, 2018). Kemampuan HOTS meliputi kemampuan dalam menyelesaikan masalah, kemampuan berpikir kreatif, serta kemampuan untuk berpikir secara kritis. Kemampuan HOTS ini sangat penting dalam menyelesaikan permasalahan matematika terutama pada permasalahan yang bersifat tidak rutin sehingga memerlukan kreatifitas dan kemampuan berfikir kritis dalam menyelesaikannya (Lailly \& Wisudawati, 2015). HOTS mempunyai dua ciri khas yaitu kritis dan kreatif. Berdasarkan taksonomi bloom aspek yang termasuk dalam kemampuan berpikir kritis yaitu menganalisis dan mengevaluasi, sedangkan untuk aspek yang termasuk dalam kemampuan berpikir kreatif yaitu mencipta. Kesimpulannya indikator HOTS yaitu mencakup kata kerja operasional menganalisis, mengevaluasi, dan mencipta (Hidayati, 2017).

Penelitian ini relevan dengan penelitian Astuti (2017) tentang representasi matematis mahasiswa dalam menyelesaikan masalah matematika yang mengatakan bahwa kemampuan representasi mahasiswa Subjek-1 dan Subjek -2 berada pada kategori baik, sedangkan kemampuan representasi mahasiswa Subjek-3 berada pada kategori rendah. Penelitian ini juga relevan dengan penelitian Yekti (2018) yang mengatakan bahwa mahasiswa dengan presetasi belajar mata kuliah program linear tinggi mempunyai kemampuan representasi matematis yang sangat baik, mahasiswa dengan prestasi belajar mata kuliah program linear sedang mempunyai kemampuan representasi matematis yang baik, sedangkan mahasiswa dengan prestasi belajar mata kuliah program linear yang rendah mempunyai kemampuan representasi matematis yang masih kurang.

Berdasarkan fakta di lapangan, masih banyak mahasiswa yang tidak tepat dan tidak konsisten dalam menuliskan simbol-simbol matematika. Mahasiswa cenderung fokus pada pencapaian hasil akhir dari penyelesaian soal saja tanpa memperhatikan penulisan simbol-simbol matematikanya. Padahal penentuan hasil akhir dari suatu soal sangat bergantung pada penulisan simbolsimbol matematika yang digunakan. Jika terdapat kesalahan dalam penulisan simbol-simbol matematika maka dapat mengakibatkan kesalahan dalam penentuan hasil akhir dari penyelesaian suatu soal. Hal diperkuat dengan penelitian Subekti, Untarti, \& Gunawan (2016) yang mengatakan bahwa kesalahan jawaban mahasiswa dalam menyelesaikan soal statistik deskriptif ditinjau dari kemampuan komunikasi matematis yaitu sebesar $36,11 \%$ disebabkan karena tidak konsisten dalam menuliskan simbol-simbol matematika.

Penelitian ini bertujuan untuk mendeskripsikan kesalahan representasi simbolik yang dilakukan oleh mahasiswa jenjang Strata-1 prodi teknik sipil di Universitas Muhammadiyah Malang dalam menyelesaikan permasalahan matematika. Penelitian ini bermanfaat untuk mengetahui kesalahan representasi simbolik yang dilakukan oleh mahasiswa jenjang Strata-1 prodi Teknik Sipil di Universitas Muhammadiyah Malang dan menentukan upaya yang dapat dilakukan untuk mengatasi kesalahan tersebut. 
DOI: https://doi.org/10.24127/ajpm.v8i3.2265

\section{METODE PENELITIAN}

Penelitian ini menggunakan pendekatan kualitatif dan jenis penelitian deskriptif. Subjek dalam penelitian ini meliputi meliputi 9 mahasiswa prodi Teknik Sipil di Universitas Muhammadiyah Malang. Prosedur penelitian diawali dengan menentukan permasalahan berdasarkan keadaan di lapangan yaitu banyaknya mahasiswa yang tidak menuliskan simbol dengan baik dalam menyelesaikan soal. Tahapan kedua yaitu melakukan studi literatur terkait kesalahan penulisan simbol dalam matematika. Tahapan ketiga yaitu menetapkan mahasiswa prodi Teknik Sipil sebagai subjek penelitian. Tahapan keempat yaitu melakukan studi pendahuluan terkait penelitian terdahulu yang relevan dengan penelitian ini. Tahapan kelima yaitu menetapkan metode yang digunakan dalam penelitian yaitu dokumentasi dan tes yang berupa soal HOTS pada Lembar Kegiatan Mahasiswa (LKM) yang memuat kegiatan rangkuman, diskusi, dan refleksi dengan materi turunan parsial yang mencakup indikator soal HOTS menganalisis, mengevaluasi, dan mencipta. Tahapan keenam yaitu melakukan analisis data dengan mengidentifikasi jenis kesalahan yang dilakukan oleh mahasiswa dan mengelompokkan kesalahan tersebut berdasarkan indikator soal HOTS. Tahapan ketuju yaitu menuliskan hasil penelitian dalam bentuk deskriptif.

Teknik pengumpulan data yang digunakan pada penelitian ini adalah dokumentasi dan tes. Tes yang digunakan merupakan soal HOTS dengan indikator soal analisis, evaluasi, dan mencipta. Analisis tes ini difokuskan terhadap representasi simbolik pada penyelesaian soal HOTS. Mengadaptasi pendapat kebutuhan penelitian, indikator representasi simbolik pada penelitian ini, merujuk pada Suryana (2012) yang disajikan pada Tabel 1.

Tabel 1. Indikator representasi simbolik berdasarkan indikator soal HOTS

\begin{tabular}{|c|c|}
\hline Indikator Soal HOTS & Indikator Representasi Simbolik \\
\hline Analisis & $\begin{array}{l}\text { 1. Membuat representasi simbolik dari representasi } \\
\text { verbal yang diberikan } \\
\text { 2. Menyelesaikan masalah menggunakan representasi } \\
\text { simbolik yang tepat }\end{array}$ \\
\hline Evaluasi & $\begin{array}{l}\text { 1. Membuat representasi simbolik dari representasi } \\
\text { verbal yang diberikan } \\
\text { 2. Menyelesaikan masalah menggunakan representasi } \\
\text { simbolik yang tepat }\end{array}$ \\
\hline Mencipta & $\begin{array}{l}\text { 1. Membuat representasi simbolik dari representasi } \\
\text { verbal yang diberikan } \\
\text { 2. Menyelesaikan masalah menggunakan representasi } \\
\text { simbolik yang tepat }\end{array}$ \\
\hline
\end{tabular}

Teknik analisis data pada penelitian kualitatif melalui beberapa tahapan. Tahapan pertama yaitu tahapan reduksi, dengan mengambil 23 LKM untuk diambil datanya sedangkan 16 LKM lainnya tidak diambil karena jawaban kosong, dan jawaban terindikasi mencontek. Berdasarkan 23 LKM yang telah diambil datanya, dipilih 9 LKM untuk dikaji lebih rinci. Tahapan kedua yaitu penyajian data. Tahapan ini data hasil tes dianalisis dan 
disajikan dalam bentuk deskripsi. Data ini memuat kesalahan representasi simbolik dari representasi lainnya yang diberikan, dan kesalahan dalam menggunakan ekspresi matematis. Tahapan ketiga yaitu penarikan kesimpulan. Penarikan kesimpulan berdasarkan data dan hasil analisis. Tahapan keempat yaitu verifikasi data dengan melakukan tinjauan kembali penelitian sebelumnya untuk membandingkan hasil analisis data penelitian.

\section{HASIL PENELITIAN DAN PEMBAHASAN}

Berdasarkan hasil pengerjaan mahasiswa pada LKM yang telah diberikan diambil 9 LKM untuk dikaji lebih rinci. Berikut adalah deskripsi 6jenis kesalahan representasi simbolik dalam menyelesaiakan soal turunan parsial. Berikut ini merupakan hasil pengerjaan mahasiswa pada LKM pada indikator soal HOTS analisis.

2. Diketahui $f(x, y)=2 x+5 y$, lengkapi tabel berikut dengan menggunakan simbol turunan parsial

\begin{tabular}{|c|c|c|c|}
\hline No & Pertanyaan & Turunan parsial terhadap $x$ & Turgnan parsial terhadap $y$ \\
\hline a. & $\begin{array}{l}\text { Tentukan turunan } \\
\text { parsial dari } f(x, y)\end{array}$ & $\begin{aligned} & \partial x \\
= & 2-0 \\
= & 2\end{aligned}$ & 6 \\
\hline b. & $\begin{array}{l}\text { Tentukan nilai fungsi } \\
\text { turunan parsial dari } \\
f(x, y) \text { saat } x=1 \text { dan } \\
y=-1\end{array}$ & $\begin{array}{c}f(x, y)=2 x+5 y \\
-f x\left(\frac{1}{x, y}\right)=2 \\
f x(1,-1)=2\end{array}$ & $\begin{array}{l}x, y)=2 x+5 y \\
y(x, y)=5 \\
y(1,-1)=5\end{array}$ \\
\hline
\end{tabular}

Gambar 1. Kesalahan penulisan simbol turunan parsial pada soal analisis

Berdasarkan Gambar 1 terlihat bahwa terdapat kesalahan dalam penulisan simbol turunan parsial. Kesalahan ini termasuk dalam indikator representasi simbolik yaitu membuat representasi simbolik dari representasi verbal yang diberikan. Representasi simbolik yang benar yaitu $f_{x}(x, y)$ untuk simbol turunan parsial terhadap $x$ dan $f_{y}(x, y)$ untuk simbol turunan parsial terhadap $y$. Namun mahasiswa menuliskan $f^{\prime}(x, y)$ sebagai simbol turunan parsial. Kesalahan tersebut disebabkan karena tidak memahami simbol-simbol turunan parsial. Hal ini sejalan dengan penelitian Irfan (2017) yang menyebutkan bahwa kecemasan yang tinggi pada matematika menyebabkan timbulnya beberapa kesalahan diantaranya yaitu, keselahan dalam penulisan simbol matematika, pemaknaan model matematika, dan tidak konsisten dalam menggunakan simbol matematika.

Berdasarkan Gambar 1 juga terdapat kesalahan dalam penulisan hasil turunan parsial dari persamaan $f(x, y)$ terhadap $y$. Kesalahan ini termasuk dalam indikator representasi simbolik yaitu menyelesaikan masalah menggunakan representasi simbolik yang tepat. Representasi simbolik yang benar yaitu $f_{y}(x, y)$ bernilai 5 namun tertuliskan -5 . Kesalahan tersebut disebabkan karena ketidaktelitian dalam mengerjakan soal. Hal ini sejalan dengan penelitian Yusnia \& Fitriyani (2010) yang menyebutkan bahwa $42,98 \%$ kesalahan terjadi pada tahapan keterampilan proses yaitu kesalahan dalam melakukan perhitungan. 
DOI: https://doi.org/10.24127/ajpm.v8i3.2265

2. Diketahui $f(x, y)=2 x+5 y$, lengkapi tabel berikut dengan menggunakan simbol turunan parsial yang benar!

\begin{tabular}{|c|c|c|c|}
\hline No & Pertanyaan & Turunan parsial terhadap $x$ & Turunan parsial terhadap $y$ \\
\hline a. & $\begin{array}{l}\text { Tentukan turunan } \\
\text { parsial dari } f(x, y)\end{array}$ & $\frac{f}{5 x}(x, y) / \frac{\partial f(x, y)}{d x}$ & \\
\hline b. & $\begin{array}{l}\text { Tentukan nilai fungsi } \\
\text { turunan parsial dari } \\
f(x, y) \text { saat } x=1 \text { dan } \\
y=-1\end{array}$ & $\begin{array}{l}f(x, y)=2 x+5 y \\
f x(x, y)=2 \\
f+(1,-1)=2\end{array}$ & $\begin{array}{l}f(x, y)=7 x+5 y \\
f y(x, y)=5 \\
f y(1,-1)=5\end{array}$ \\
\hline
\end{tabular}

Gambar 2. Kesalahan menentukan hasil turunan parsial pada soal analisis

Berdasarkan Gambar 2 terlihat bahwa penulisan simbol turunan parsial sudah benar, namun tidak menuliskan hasil turunan parsial dari persamaan $f(x, y)=2 x+5 y$ terhadap $x$ dan $y$. Kesalahan ini termasuk dalam indikator representasi simbolik yaitu menyelesaikan masalah menggunakan representasi simbolik yang tepat. Hasil turunan parsial dari persamaan $f(x, y)=2 x+5 y$ terhadap $x$ dan $y$ adalah $f_{x}(x, y)=2$ dan $f_{y}(x, y)=5$. Kesalahan ini terjadi karena tidak memperhatikan perintah soal. Hal ini sejalan dengan penelitian Hidayah (2016) yang menyebutkan bahwa kesalahan dalam memahami soal sebesar $5,00 \%$ yang terjadi karena kurangnya ketelitian dan cermat dalam membaca soal.

2. Diketahui $f(x, y)=2 x+5 y$, lengkapi tabel berikut dengan menggunakan simbol turunan parsial

\begin{tabular}{l} 
yang benar! \\
\begin{tabular}{|l|l|l|l|}
\hline No & \multicolumn{1}{|c|}{ Pertanyaan } & Turunan parsial terhadap $x$ & Turunan parsial terhadap $y$ \\
\hline a. & $\begin{array}{l}\text { Tentukan turunan } \\
\text { parsial dari } f(x, y)\end{array}$ & $f_{x}(x, y)=2$ & $f_{y}(x, y)=5$ \\
\hline b. & $\begin{array}{l}\text { Tentukan nilai fungsi } \\
\text { turunan parsial dari } \\
f(x, y) \text { saat } x=1 \text { dan } \\
y=-1\end{array}$ & $f_{x}(x, y)=2$ & $f_{y}(x, y)=5$ \\
$f_{x}(1,-1)=1$
\end{tabular} \\
\hline
\end{tabular}

Gambar 3. Kesalahan menentukan nilai fungsi dari turunan parsial pada soal analisis

Berdasarkan Gambar 3 terlihat bahwa penulisan simbol turunan parsial dan jawaban untuk hasil turunan parsial dari persamaan $f(x, y)=2 x+5 y$ terhadap $x$ dan $y$ sudah benar, akan tetapi terdapat kesalahan dalam menentukan nilai fungsi turunan parsial terhadap $x$ saat $x=1$ dan $y=-1$. Kesalahan ini termasuk dalam indikator representasi simbolik yaitu menyelesaikan masalah menggunakan representasi simbolik yang tepat. Hasil fungsi turunan parsial terhadap $x$ saat $x=1$ dan $y=-1$ yang benar adalah $f_{x}(1,-1)=2$. Kesalahan tersebut disebabkan karena ketidaktelitian dalam mengerjakan soal dan menuliskan jawaban soal tersebut. Hal ini sejalan dengan penelitian Utami (2016) yang menyebutkan bahwa kesalahan dalam pemeriksaan perhitungan sehingga salah dalam menuliskan hasil akhir termasuk dalam kategori encoding. 
DOI: https://doi.org/10.24127/ajpm.v8i3.2265

Berikut ini merupakan hasil indikator soal HOTS evaluasi: pengerjaan mahasiswa pada LKM pada

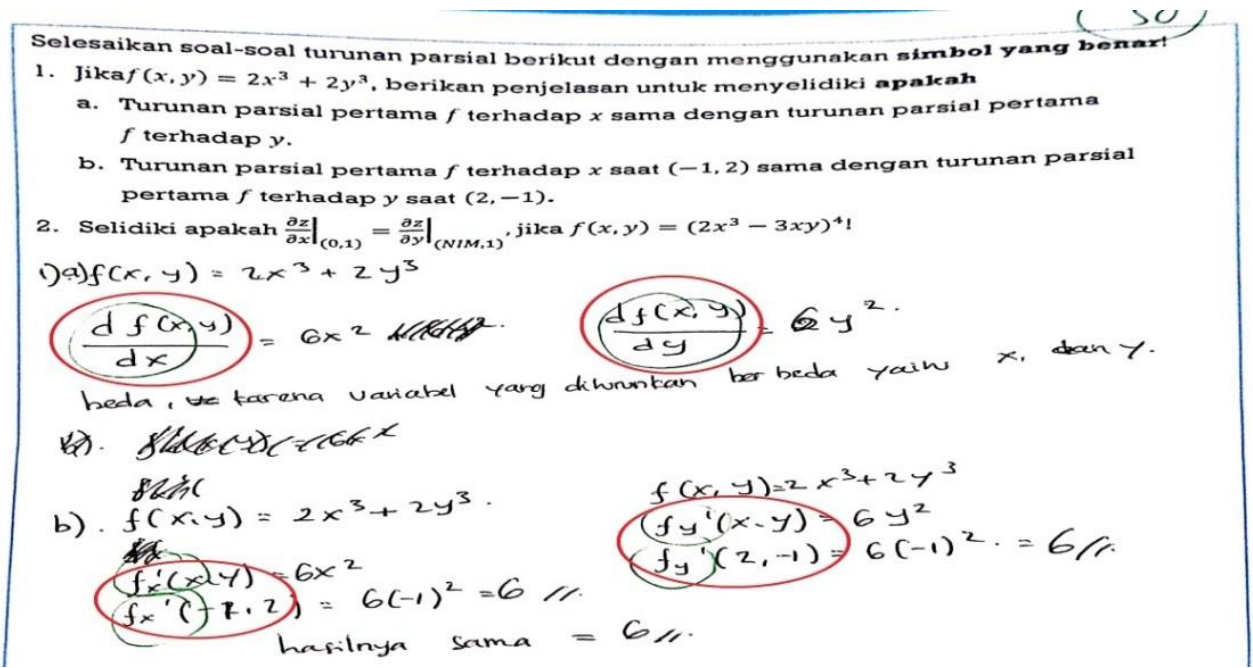

Gambar 4. Kesalahan dalam menuliskan simbol turunan parsial pada soal evaluasi

Berdasarkan Gambar 4 terlihat bahwa hasil turunan parsial dari persamaan $\quad f(x, y)=2 x^{3}+2 y^{3}$ terhadap $x$ dan $y$ sudah benar, namun terdapat kesalahaan dalam penulisan simbol turunan parsial. Kesalahan ini termasuk dalam indikator representasi simbolik yaitu membuat representasi simbolik dari representasi verbal yang diberikan. Representasi simbolik yang benar yaitu $f_{x}(x, y)=\frac{\partial f}{\partial x}$ untuk simbol turunan parsial terhadap $x$ dan $f_{y}(x, y)=\frac{\partial f}{\partial y}$ untuk simbol turunan parsial terhadap $y$. Kesalahan ini terjadi karena tidak memahami simbol turunan parsial. Hal ini sejalan dengan penelitian Sumadiasa (2014) yang menyatakan bahwa kesalahan penulisan simbol turunan termasuk kedalam jenis kesalahan fakta.

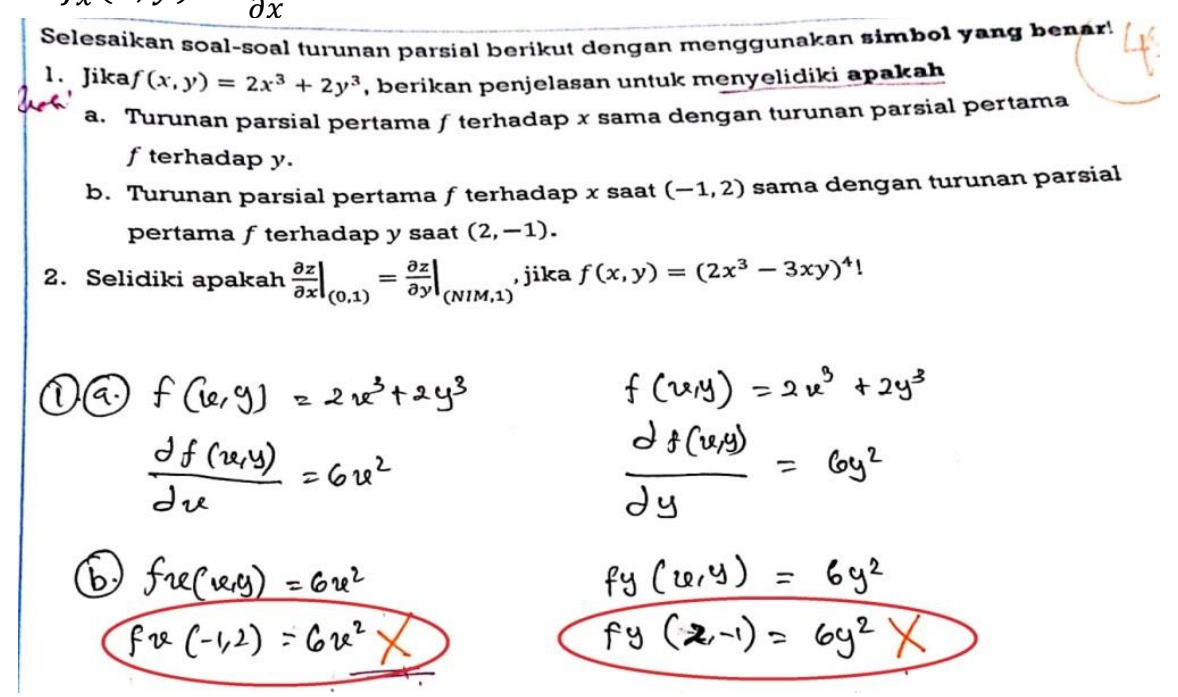

Gambar 5. Kesalahan menentukan nilai fungsi turunan parsial pada soal evaluasi 
DOI: https://doi.org/10.24127/ajpm.v8i3.2265

Berdasarkan Gambar 5 terlihat bahwa penulisan simbol turunan parsial telah dituliskan dengan benar dan hasil dari turunan parsial dari persamaan $f(x, y)=2 x^{3}+2 y^{3}$ terhadap $x$ dan $y$ pun sudah benar, namun terdapat kesalahan dalam menentukan nilai fungsi turunan parsial dari persamaan $f(x, y)=2 x^{3}+2 y^{3}$ terhadap $x$ saat $(-1,2)$ dan terhadap $y$ saat $(2,-1)$. Kesalahan ini termasuk dalam indikator representasi simbolik yaitu menyelesaikan masalah menggunakan representasi simbolik yang tepat. Hasil fungsi turunan parsial dari persamaan $f(x, y)=2 x^{3}+2 y^{3}$ terhadap $x$ saat $(-1,2)$ dan terhadap $y$ saat $(2,-1)$ yang benar yaitu $f_{x}(-1,2)=6$ dan $f_{y}(2,-1)=6$. Kesalahan ini terjadi karena tidak tidak memahami konsep dalam menentukan nilai dari suatu fungsi. Hal ini sejalan dengan penelitian Abidin (2012) yang menyebutkan bahwa mahasiswa melakukan kesalahan pada saat menyelesaikan soal trigonomteri berupa kesalahan dalam memahami konsep sebesar 25,26\%.

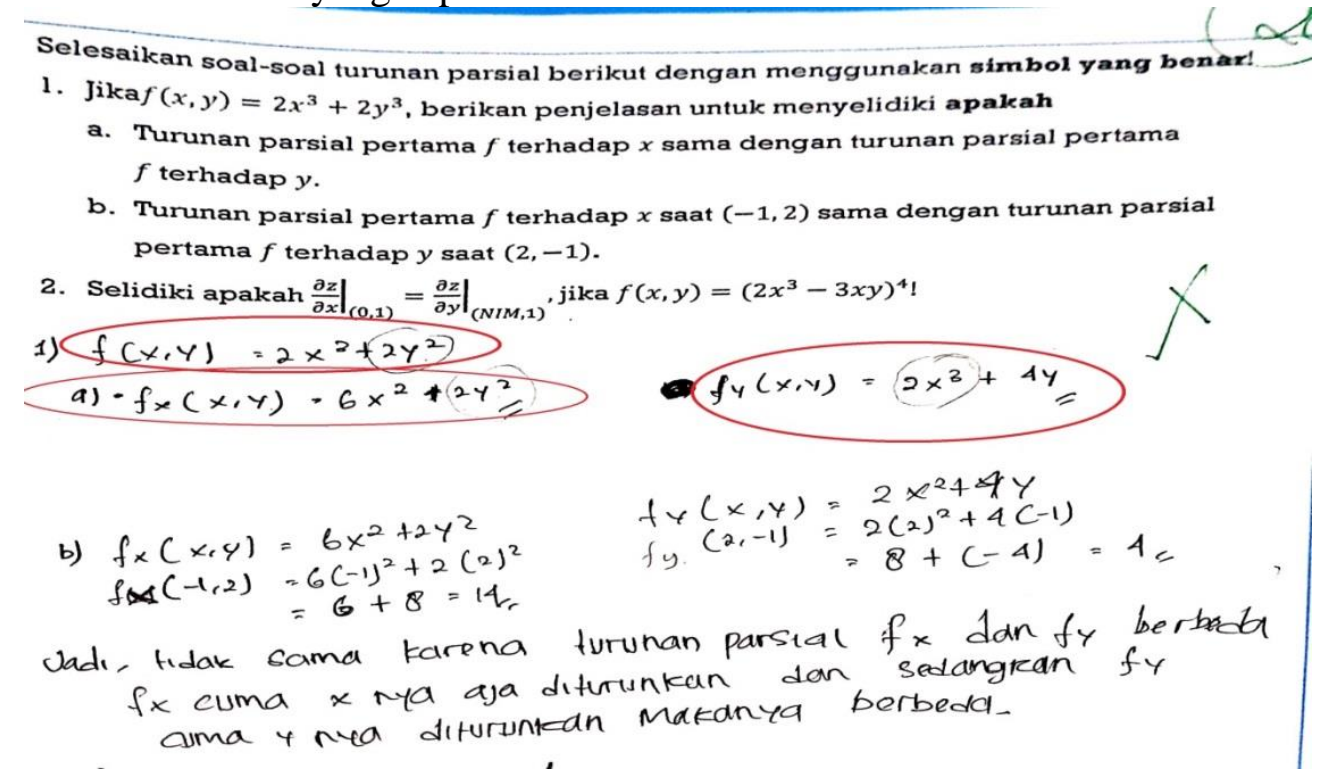

Gambar 6. Kesalahan menentukan hasil turunan parsial pada soal evaluasi

Berdasarkan Gambar 6 terlihat bahwa terjadi kesalahan penulisan fungsi $f$ dan kesalahan dalam menentukan hasil turunan parsial dari persamaan $\quad f(x, y)=2 x^{3}+2 y^{3}$ terhadap $x$ dan $y$. Kesalahan ini termasuk dalam indikator representasi simbolik yaitu menyelesaikan masalah menggunakan representasi simbolik yang tepat. Hasil turunan parsial dari persamaan $\quad f(x, y)=2 x^{3}+2 y^{3}$ terhadap $x$ dan $y$ yang benar yaitu $f_{x}(x, y)=6 x^{2}$, dan $f_{y}(x, y)=6 y^{2}$. Kesalahan ini terjadi karena tidak memperhatikan soal dan tidak memahami konsep turunan parsial dengan baik. Hal ini sejalan dengan penelitian Ardiawan (2015) yang menyebutkan bahwa kesalahan yang dilakukan oleh mahasiswa laki - laki dan perempuan dalam mengerjakan soal induksi matematika yaitu kesalahan dalam memahami konsep dan prosedur induksi matematika.

Berikut ini merupakan hasil pengerjaan mahasiswa pada LKM pada indikator soal HOTS mencipta: 


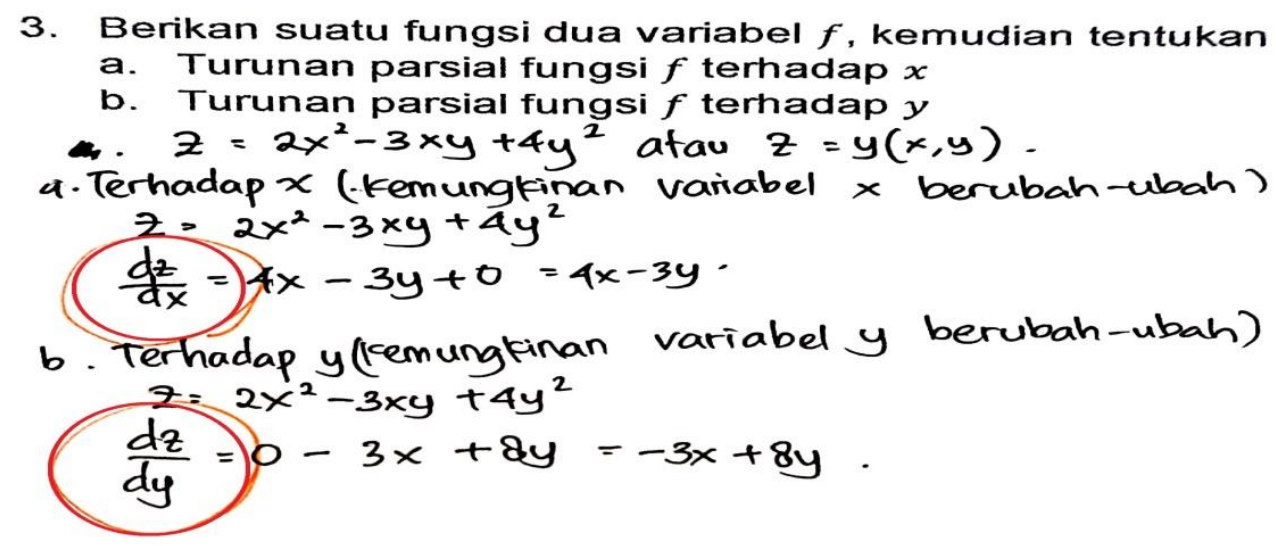

Gambar 7. Kesalahan menuliskan simbol turunan parsial pada soal mencipta

Berdasarkan Gambar 7 terlihat bahwa hasil turunan parsial dari persamaan $\quad z=2 x^{2}-3 x y+4 y^{2}$ terhadap $x$ dan $y$ sudah benar, namun terdapat kesalahan dalam menuliskan simbol turunan parsial. Kesalahan ini termasuk dalam indikator representasi simbolik yaitu membuat representasi simbolik dari representasi verbal yang diberikan. Hasil turunan parsial fungsi $z$ terhadap $x$ dan $y$ yang benar adalah $Z_{x}(x, y)=\frac{\partial z}{\partial x}$ untuk simbol turunan parsial fungsi $z$ terhadap $x$ dan
$Z_{y}(x, y)=\frac{\partial z}{\partial y}$ untuk simbol turunan parsial fungsi $z$ terhadap $y$. Kesalahan ini terjadi karena tidak memahami simbol-simbol turunan parsial. Hal ini diperkuat dengan penelitian Paladang, Indriani, \& Dirgantoro (2018) yang menyebutkan bahwa kesalahan yang terjadi ketika mengerjakan soal matematika pada materi fungsi adalah tidak teliti dalam mengerjakan soal, tidak memahami simbol, dan tidak memahami cara membaca simbol.

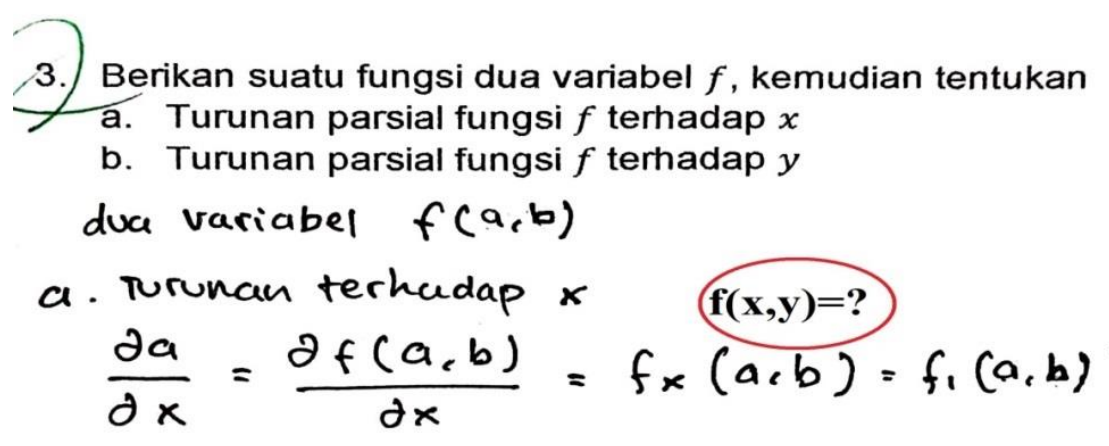

$$
\begin{aligned}
& \text { b. Turunan terhadap y } \\
& \frac{\partial a}{\partial y}=\frac{\partial f(a, b)}{\partial y}=f_{y}(a, b)=f_{2}(a, b)
\end{aligned}
$$

Gambar 8. Kesalahan pemahaman perintah soal pada soal mencipta

Berdasarkan Gambar 8 terlihat bahwa penulisan simbol turunan parsial terhadap $x$ dan $y$ sudah benar, namun terdapat kesalahan dalam menjawab soal sesuai dengan perintah soal. Kesalahan ini termasuk dalam indikator 
DOI: https://doi.org/10.24127/ajpm.v8i3.2265

representasi simbolik yaitu menyelesaikan masalah menggunakan representasi simbolik yang tepat. Perintah soal yang benar adalah menuliskan terlebih dahulu fungsi $f$ dan kemudian menentukan hasil turunan parsial fungsi $f$ terhadap $x$ dan $y$. Kesalahan ini terjadi karena tidak memperhatikan perintah soal yang diberikan dengan baik. Hal ini sejalan dengan penelitian Oktaviana (2017) yang menyebutkan bahwa 24\% mahasiswa melakukan kesalahan dalam membaca soal yaitu tidak mengetahui kunci dari soal tersebut.

3. Berikan suatu fungsi dua variabel $f$, kemudian tentukan

a. Turunan parsial fungsi $f$ terhadap $x$

b. Turunan parsial fungsi $f$ terhadap $y$

a). $f(x \cdot y)=3 x^{2}+2 x y+4 y^{2}$

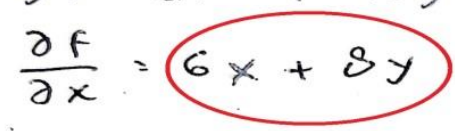

b). $f(x, y)=2 x^{2}+4 x y-3 y^{2}$

$$
\frac{\partial f}{\partial y}=4 x-6 y
$$

Gambar 9. Kesalahan hasil turunan parsial pada soal mencipta

Berdasarkan Gambar 9 terlihat bahwa penulisan simbol turunan parsial telah dituliskan dengan benar, namun terdapat kesalahan dalam menentukan hasil dari turunan parsial fungsi $f$ terhadap $x$. Kesalahan ini termasuk dalam indikator representasi simbolik yaitu menyelesaikan masalah menggunakan representasi simbolik yang tepat. Hasil turunan parsial dari fungsi $f(x, y)=3 x^{2}+2 x y+4 y^{2}$ terhadap $x$ adalah $f_{x}(x, y)=\frac{\partial f}{\partial x}=6 x+$ $2 y$. Kesalahan ini terjadi karena tidak teliti dalam mengerjakan soal. Hal ini sejalan dengan penelitian Farida (2015) yang menyebutkan bahwa salah satu kesalahan dan penyebab terjadinya kesalahan dalam menyelesaikan soal cerita matematika yaitu kesalahan perhitungan yang terjadi karena terburuburu dan kurang teliti dalam melakukan perhitungan. Hasil analisis ini diperkuat Sulistyaningsih \& Rakhmawati (2017) bahwa kesalahan perhitungan (komputasi) terjadi karena kurang teliti dalam melakukan perhitungan dan kurang memahami konsep operasi bilangan bulat.

\section{KESIMPULAN DAN SARAN}

Berdasarkan hasil penelitian yang telah dilakukan, kesalahan representasi simbolik yang terjadi pada mahasiswa prodi Teknik Sipil di Universitas Muhammadiyah Malang pada indikator soal HOTS analisis berupa kesalahan dalam menuliskan simbol turunan parsial yang disebabkan karena tidak memahami simbol-simbol turunan parsial, kesalahan dalam menentukan hasil dari turunan parsial suatu fungsi disebabkan karena ketidaktelitian dalam mengerjakan soal dan tidak memperhatikan perintah soal dengan baik, dan kesalahan dalam menentukan nilai dari suatu fungsi disebabkan karena ketidaktelitian dalam 
DOI: https://doi.org/10.24127/ajpm.v8i3.2265

mengerjakan soal dan menuliskan jawaban soal.

Kesalahan representasi simbolik yang terjadi pada indikator soal HOTS evaluasi yaitu kesalahan dalam menuliskan simbol turunan parsial yang terjadi karena tidak memahami simbolsimbol turunan parsial, kesalahan dalam menentukan nilai fungsi turunan parsial yang terjadi karena tidak memahami konsep dalam menentukan nilai suatu fungsi, dan kesalahan dalam menentukan hasil turunan parsial yang terjadi karena tidak memperhatikan soal dan tidak memahami konsep turunan parsial dengan baik.

Kesalahan representasi simbolik pada indikator soal HOTS mencipta yaitu kesalahan menuliskan simbol turunan parsial yang disebabkan karena tidak memahami simbol-simbol turunan parsial, kesalahan memahami perintah soal yang disebabkan karena tidak memperhatikan perintah soal yang diberikan dengan baik, dan kesalahan menentukan hasil turunan parsial yang disebabkan karena tidak teliti dalam mengerjakan soal.

Berdasarkan hasil yang diperoleh dari penelitian ini maka perlu adanya upaya dalam mengatasi kesalahan-kesalahan representasi simbolik yang dilakukan oleh mahasiswa. Salah satu upaya yang dapat dilakukan adalah tidak hanya memperhatikan hasil akhir dari penyelesaian soal tersebut saja, melainkan lebih menekankan dan lebih memperhatikan lagi representasi simbolik yang digunakan oleh mahasiswa. Upaya yang dapat dilakukan oleh dosen dalam menghadapi kesalahan representasi ini salah satunya adalah dengan memberikan LKM (Lembar Kegiatan Mahasiswa) yang lebih menekankan pada representasi simbolik, agar mahasiswa terbiasa untuk menyelesaikan soal dengan representasi simbolik yang baik. Selain dosen, upaya untuk mengatasi kesalahan representasi simbolik juga dilakukan oleh mahasiswa yaitu lebih memahami dan memperhatikan kembali representasi simbolik dalam menyelesaikan soal. Upaya lain juga dapat dilakukan oleh guru pada jenjang pendidikan sekolah dasar hingga sekolah menengah atas yaitu tidak hanya memfokuskan penyelesaian soal pada jawaban akhir saja, namun juga membiasakan siswanya untuk menuliskan simbol-simbol dan menyelesaikan soal dengan baik. Penelitian berikutnya diharapkan dapat memperluas cakupan pembahasan tidak hanya fokus pada representasi simbolik saja melainkan juga pada bentuk-bentuk representasi lainnya.

\section{DAFTAR PUSTAKA}

Abidin, Z. (2012). Analisis Kesalahan Mahasiswa Prodi Pendidikan Matematika Fakultas Tarbiyah IAIN Ar - Raniry dalam Mata Kuliah Trigonometri dan Kalkulus 1. Jurnal Ilmiah DIDAKTIK, XIII(1), 183-196.

Ardiawan, Y. (2015). Analisis Kesalahan Mahasiswa dalam Menyelesaikan Soal Induksi Matematika di IKIP PGRI Pontianak. Jurnal Pendidikan Informatika Dan Sains, 4(1), 147163.

Astuti, E. P. (2017). Representasi Matematis Mahasiswa Calon Guru dalam Menyelesaikan Masalah Matematika. Beta Jurnal Tadris Matematika, 10(1), 70-82. https://doi.org/10.20414/betajtm.v1 $\underline{0 \mathrm{i} 1.100}$ 
Dinni, H. N. (2018). HOTS (High Order Thinking Skills) dan Kaitannya dengan Kemampuan Literasi Matematika. Prisma, Prosiding Seminar Nasional Matematika, 1, 170-176.

Farida, N. (2015). Analisis Kesalahan Siswa SMP Kelas VIII dalam Menyelesaikan Soal Cerita Matematika. Aksioma, 4(2), 42-52. Handayani, H. (2015). Pengaruh Pembelajaran Kontekstual Terhadap Kemampuan Pemahaman dan Representasi Matematis Siswa Sekolah Dasar. Didaktik: Jurnal Pendidikan Guru Sekolah Dasar, I(1), 142-149.

Hapizah, D. (2019). Teacher's Abilities of Translation of Symbolic Representation to Visual Representation and Vice Versa: Addition of Integers. International Journal of Pedagogy and Teacher Education (IJPTE), 3(1), 41-50.

Hartoyo, A. (2010). Mode Representasi Ide dalam Belajar Matematika. Jurnal Pendidikan Matematika Dan IPA, 1(1), 1-10.

Hidayah, S. (2016). Analisis Kesalahan Siswa dalam Menyelesaikan Soal Cerita SPLDV Berdasarkan Langkah Penyelesaian Polya. Prosiding Seminar Nasional Pendidikan Matematika, 1, 182190.

Hidayati, A. U. (2017). Melatih Keterampilan Berpikir Tingkat Tinggi dalam Pembelajaran Matematika pada Siswa Sekolah Dasar. Jurnal Pendidikan Dan Pembelajaran Dasar, 4(2), 143156.

Irfan, M. (2017). Analisis Kesalahan Siswa dalam Pemecahan Masalah Berdasarkan Kecemasan Belajar Matematika. Kreano, Jurnal Matematika Kreatif-Inovatif, 8(2),
143-149.

https://doi.org/10.15294/kreano.v8i 2.8779

Khairunnisa, G. F., Rahman, A., \& Susanto, H. (2018). Keberhasilan Siswa dalam Menyelesaikan Soal Cerita Berdasarkan Kemampuan Membuat Berbagai Representasi Matematis. Jurnal Pendidikan, 3(6), 723-730.

Lailly, N. R., \& Wisudawati, A. W. (2015). Analisis Soal Tipe Higher Order Thinking Skill (HOTS) dalam Soal UN Kimia SMA Rayon B Tahun 2012/2013. Kaunia, 11(1), 27-39.

Maoto, S., Masha, K., \& Mokwana, L. (2018). Teachers' Learning and Assessing of Mathematical Processes with Emphasis on Representations, Reasoning and Proof. Pythagoras, 39(1), 1-10. https://doi.org/10.4102/pythagoras. v39i1.373

Oktaviana, D. (2017). Analisis Tipe Kesalahan Berdasarkan Teori Newman dalam Menyelesaikan Soal Cerita pada Mata Kuliah Matematika Diskrit. Edu Sains: Jurnal Pendidikan Sains \& Matematika, 5(2), 22-32. https://doi.org/10.23971/eds.v5i2.7 $\underline{19}$

Paladang, K. K., Indriani, S., \& Dirgantoro, K. P. S. (2018). Analisis Kesalahan Siswa Kelas VIII SLH Medan dalam Mengerjakan Soal Matematika Materi Fungsi Ditinjau dari Prosedur Newman [Analyzing Students' Errors in Solving Mathematics Problems in Function Topics Based on Newman'S Procedures in Grade 8 At SLH Medan. JOHME: Journal of Holistic Mathematics Education, 
DOI: https://doi.org/10.24127/ajpm.v8i3.2265

1(2), 93-103. https://doi.org/10.19166/johme.v1i 2.798

Rodiawati, A. (2018). Worked Example Using ILL-Structured Problem: Trained High Order Thinking Skill. AKSIOMA Jurnal Pendidikan Matematika FKIP Univ. Muhammadiyah Metro, 7(2), 308-313.

Sabirin, M. (2014). Representasi dalam Pembelajaran Matematika. Jurnal Pendidikan Matematika, 1(2), 3344.

https://doi.org/10.18592/jpm.v1i2. $\underline{49}$

Subekti, F. E., Untarti, R., \& Gunawan. (2016). Identifikasi kesalahan jawaban mahasiswa ditinjau dari kemampuan komunikasi matematis. 2(2), 41-52.

Sulistyaningsih, A., \& Rakhmawati, E. (2017). Analisis Kesalahan Siswa Menurut Kastolan Dalam Pemecahan Masalah Matematika. Matematika, 19(2), 123-130.

Sumadiasa, I. G. (2014). Analisis Kesalahan Siswa Kelas VIII SMP Negeri 5 Dolo dalam Menyelesaikan Soal Luas Permukaan dan Volume Limas. Jurnal Elektronik Pendidikan Matematika Universitas Tadulako, 1(2), 197-203.

Suryana, A. (2012). Kemampuan Berpikir Matematis Tingkat Lanjut (Advanced Mathematical Thinking) dalam Mata Kuliah Statistika Matematika 1. Prosiding Seminar Nasional Matematika Dan Pendidikan Matematika FMIPA UNY, 5(November), 978-979.
Utami, A. D. (2016). Tipe Kesalahan Mahasiswa dalam Menyelesaikan Soal-Soal Geometri Berdasar Newman'S Error Analysis (NEA). JIPM (Jurnal Ilmiah Pendidikan Matematika), 4(2), 85-92. https://doi.org/10.25273/jipm.v4i2. 842

Yekti, S. M. P. (2018). Kemampuan Representasi Matematis Mahasiswa pada Mata Kuliah Pemodelan Matematika Ditinjau dari Prestasi Belajar Program Linier. Journal of Chemical Information and Modeling, 3(2), 1689-1699.

https://doi.org/10.1017/CBO97811 07415324.004

Yusnia, D., \& Fitriyani, H. (2010). Identifikasi Kesalahan Siswa Menggunakan Newman'S Error Analysis (NEA) pada Pemecahan Masalah Operasi Hitung Bentuk Aljabar. Seminar Nasional Pendidikan, Sains Dan Teknologi, 78-83. 